\title{
Political Economy of Connectivity: China's Belt and Road Initiative
}

\author{
Tolga Demiryol \\ Altinbas University, Istanbul, Turkey,tolga.demiryol@altinbas.edu.tr
}

\begin{abstract}
There are ongoing academic and public debates on the nature of China's Belt and Road Initiative (BRI). While some observers hold that the BRI is primarily about economic development, others see it as a grand strategy of a great power with hegemonic aspirations. Is the BRI about development or geopolitics? This article adopts a political economy approach to bridge the developmental and geopolitical perspectives. The main argument is that the BRI signifies an attempt by the Chinese state to manage internal problems of capital accumulation by externalizing development on a trans-regional scale. The problems of capital accumulation under China's export-oriented growth model indicates a particular form of spatial fix via the BRI, which goes beyond the exportation of excess industrial/financial capacity and seeks to transform external productive spaces through inter-regional connectivity. The process of constructing new nodes and infrastructures of capital creates space for new forms of asymmetric interdependencies, rendering it prohibitively costly for most BRI partners to exit China-centered networks. To the extent that such asymmetric dependencies can be leveraged for strategic purposes, the BRI serves a geopolitical as well as a developmental function.
\end{abstract}

KEYWORDS: China, the Belt and Road Initiative, geopolitics, development, interdependence

\section{Introduction}

President of the People's Republic of China, Xi Jinping, announced the Belt and Road Initiative (BRI) in late 2013. Since then the BRI has evolved, expanding not only in terms of geographic scale but also ambition. The BRI initially involved 65 countries - mostly across Eurasia- covering 30 percent of the world's GNP, 62 percent of population, and 75 percent of the proven energy reserves (World Bank 2018). As of 2019, the BRI is an essentially global project, encompassing all countries willing to participate. Speaking at the Belt and Road Forum in Beijing in 2017, President Xi defined the BRI as "project of the century" that "will benefit people across the world" (Xinhua 2017). The expanding margins of the BRI reflect the official narrative that it is an inclusive and participatory project of shared economic development.

Not everyone is convinced by this rhetoric of openness and win-win cooperation. Sceptics consider the ambitions of the BRI as evidence for China's assertiveness in international affairs (Callahan 2016; Chang-Liao 2016; Ferdinand 2016; Y. Wang 2016). Arguments underlining China's ambitions as a rising power are grounded in the long-standing debates regarding hegemonic transitions (Allison 2017). Offensive realists in particular have argued that China cannot rise peacefully and as its capabilities increase, it will inevitably become more aggressive and purse regional hegemony (Mearsheimer 2014). Those who consider the BRI a hegemonic project often point out that China's foreign policy direction has become more proactive and globally-driven $(\mathrm{H}$. $\mathrm{Yu}$ 2017). Critical shifts in foreign policy narrative including the notions such as "China Dream" of "great national rejuvenation" or "striving for achievement" are taken as further evidence for China's true intentions (Blanchard 2017, 256). Many observers are convinced that Xi abandoned Deng's long-held policy of "keeping a low profile" and is now "confident enough to openly undermine the US-led international order" (Mayer 2018, 14).

As China upsets the international order, it frequently turns to economic statecraft, understood as the systematic use of trade, investment and other economic instruments for strategic purposes (Blackwill and Harris 2016; Chin 2015; Harrell, Rosenberg, and Saravalle 2018; Huotari and Heep 2016; Norris 2016; Reilly 2013; Xiaotong and Keith 2017). In great power politics, military capabilities still remain relevant, as evidenced by China's increased spending on defense modernization (Defense Intelligence Agency 2019). Nonetheless, costs of using military force are prohibitively high for China, given both the level of economic interdependence with the US (Lee 
2018; Wright 2013) and the persistent superiority of American military capabilities (Beckley 2018). It is within this context that the BRI is often viewed as a plot by Beijing for seeking relative advantage by non-military means.

Critics often suggest that by leveraging its massive economic resources for strategic purposes, China follows in the footsteps of the US and the Marshall Plan (Diplomat 2014; S. Shen and Chan 2018; Sidaway and Woon 2017), an analogy which Chinese officials dismiss firmly and repeatedly. Foreign Minister Wang Fi said in a 2015 speech, "The Belt and Road Initiative... is born in the era of globalization. It is a product of inclusive cooperation, not a tool of geopolitics, and must not be viewed with the outdated Cold War mentality" (Ministry of Foreign Affairs of the People's Republic of China 2015). In 2018 Wang re-emphasized that the BRI is not about geopolitics: "It is neither a Marshall Plan, nor a geostrategic concept. Ever since the very beginning of proposing the Belt and Road Initiative, the Chinese side has been adhering to the principle of extensive consultation, joint contribution and shared benefits, sticking to the concept of transparency, openness and inclusiveness." (Ministry of Foreign Affairs of the People's Republic of China 2018). Or as Xi put it in his address to Boao Forum in April 2018, "The Belt and Road is not a plot of China, but a plan in sunshine" (Macaes 2019, 32).

Looking past the predictably self-serving rhetoric, some analyses underscore the developmental benefits of the BRI for the partner countries. In 2017, Asian Development Bank reported that there is a significant "infrastructure gap" in Asia requiring a capital injection of \$1.7 trillion per year (Asian Development Bank 2017). The BRI can help at least partially fill that gap. It is also often voiced that the BRI can be a template of a new phase of globalization, marked by the reopening and reintegration of markets under China's leadership (Bijian 2017; Li and Taube 2018). China appears keen on being the flag bearer of free-trade, as exemplified most vividly by Xi's 2017 keynote speech in Davos (CGTN 2017).

Even though there are various narratives about the BRI (Blanchard 2017; Clarke 2018; Sidaway and Woon 2017; Y. Wang 2016) the academic and public debate is primarily framed along the development-geopolitics axis laid out above. While some observers hold that the BRI is primarily about economic development, others see it as a grand strategy of a great power with hegemonic aspirations. Is the BRI about development or geopolitics? This article adopts a political economy approach to bridge the developmental and geopolitical perspectives. The BRI signifies an attempt by the Chinese state to manage internal problems of capital accumulation by externalizing development on a trans-regional scale. The feature that separates the BRI from historical instances of capitalist expansion is the emphasis on connectivity. The BRI does not simply aim to export excess capacity onto developing countries but rather reorganize external economic space by linking markets and producers, by multiplying and controlling trans-regional value chains. The process of constructing new nodes and infrastructures of capital also creates space for new forms of asymmetric interdependencies, rendering it prohibitively costly for most BRI partners to exit Chinacentered networks. To the extent that such asymmetric dependencies can be leveraged for strategic purposes, the BRI serves a geopolitical as well as a developmental function.

The argument is presented in two sections. First section deals with the historical processes of capital accumulation in China. While the literature on the domestic origins of the BRI emphasizes excess industrial capacity and massive foreign exchange reserves as primary drivers of infrastructure investments abroad, this section contends that overproduction issues themselves reflect the structural limits of China's capital accumulation regime. While there are various aspects of the problem of capital accumulation, ranging from rising labor costs to the political infeasibility of reforms, the main limitation is China's dependence of economic performance on global value chains, which the Chinese state and capital have limited influence over. To reduce the vulnerabilities stemming from overdependence on global supply chains, China adopted the neomercantilist policy of establishing direct (non-market) access to supplies (particularly natural resources). Dependence on global demand however, proved more difficult to manage, as indicated by the impact of the 2008 financial crisis on China's export processing sectors. To cushion the impact of demand shock, Chinese government provided a massive stimulus package in late 2008, 
which aggravated the problem of capital accumulation by creating further excess capacity, squeezing corporate profitability and increasing debt. As the limits of capital accumulation are set externally, internal policy solutions inevitably fall short.

Second section discusses how the BRI seeks to transcend the structural limitations of capital accumulation regime via externalization. The BRI involves various investment projects abroad including but not limited to massive transportation projects, which serve as spatial fixes, absorbing some of the excess industrial capacity and financial capital. More importantly, by establishing intraregional connectivity, the BRI seeks to transform, create and interconnect networks and regions to facilitate the movement of capital. The defining feature of the BRI that separates it from previous instances of capitalist expansion is the emphasis on connectivity. The BRI does not simply aim to "dump" excess capacity onto others, which would have only a limited impact, but rather reorganize external economic space by linking markets and producers, by multiplying and controlling transregional and global value chains. In the process of creating new nodes and infrastructures of capital, China also creates space for new forms of asymmetric interdependence, raising the costs of exit for others that depend on China-centered networks, which in turn indicates the geopolitical nature of the initiative. Two aspects of this process are highlighted here: the internationalization of RMB and loan-debt contractuality.

\section{Domestic Economic Liabilities}

While the global financial crisis is taken as a turning point for China's problem with excess industrial and financial capacity, evidence indicates that overproduction enters domestic policy debates well before 2008. As early as 1997, the State Council Work Report to the National People's Congress mentions "the excess production capacity of certain industries" as a major problem requiring structural adjustment (State Council 1997). Virtually every year since 2003, The National Development and Reform Commission, the primary office tasked with long-term economic planning, highlighted overproduction as a key problem for national economy (Zhang 2017, 318). "Nine traditional industries," i.e. steel, cement, plate glass, aluminum, coal, ship building, solar, wind energy and petrochemicals are identified as the culprits. In a market economy, the typical policy to combat the problem of overcapacity would be to allow the market to trim the most bloated industrial segments. However, given the importance of "performance legitimacy" for CCP, this would not be a feasible option (Sum 2018). The unwavering commitment of the party leadership to high growth would be prohibitive of any prescriptions that could result even in a temporary economic contraction.

Since late 1990s, the preferred policy to combat overaccumulation has been to redirect investment to less developed areas that could absorb the excess capacity and increase domestic demand. An early example of this policy was the Great Western Development (GWD) strategy put forward in 1999, which aimed to reduce the gap between western regions and coastal provinces. GWD initiative sought to develop China's western provinces by encouraging them to invest in infrastructure and establish trade ties with other regions. The development of these regions would have boosted demand for domestic goods and commodities. Preferential policies and large fiscal subsidies prescribed by the government, however, failed to raise growth rates sufficiently to achieve this objective.

The problem of industrial overcapacity cannot be understood in isolation from China's role in the global value chains. Following 1978 economic reforms, China integrated into a world economy that was rapidly undergoing transformation. Changes in information technology and the declining costs of transportation facilitated the coordination of different stages of production across time and space. The fragmentation of global value chains allowed developing countries to specialize in limited segments of production, taking advantage of their comparative advantages (Baldwin 2006). China relied on low labor costs and economies of scale to develop export-processing industries targeting advanced markets like the US and Japan (Zhang 2017, 316). China's WTO membership in 2001 boosted exports, allowing Beijing to maintain the momentum of growth. The share of China's total exports in GDP rose from 20.3 percent in 2001 to 36 percent in 2006 (World Bank 2019). A major source of vulnerability of the export-driven growth model, and a sign of the 
problem of overaccumulation, was rising labor costs. With rapid industrialization and the accompanying social changes, labor shortages began to appear as early as 2004, particularly in the southeastern coastal cities where export-oriented processing industries were densely located. China's nominal average wages increased more than seven-fold from 2000 to 2017 (EPS China Data 2019). While China's competitive edge eroded due to rising labor costs, the post-WTO export boom persisted mainly due to high global demand.

The accumulation of trade surplus resulted in massive foreign exchange reserves, which peaked at $\$ 3.9$ trillion in 2013 (US total reserves that year was $\$ 537$ billion). While the composition of reserves held by China's Central Bank is classified, most of the reserves are held in USDdenominated financial assets like the US Treasury Securities. Concerns about the depreciation of massive foreign reserves led Beijing to explore several venues to both rein in the rate of trade surplus accumulation and redirect the capital glut towards more productive investments. In 2005 Beijing introduced a new exchange rate rule, anchoring RMB to a basket of foreign currencies. The goal was to incrementally reduce the profitability of exports, incentivizing manufacturers to produce more for the domestic market. The redirected capital was poured into construction and infrastructure, a substantial portion of which was financed by local governments. Thus, the policies that were intended to cool down the export boom paved the way for further imbalances in the form of excessive investment in the real estate sector and rising debt (Amighini 2015, 50-51). Given the global nature of China's problem of overaccumulation domestic policies were of limited impact.

A major external initiative also driven by China's unfolding crisis of capital accumulation is the "go out" policy, encouraging firms to invest overseas, particularly in the fields of energy and infrastructure (Cabestan 2018). Chinese energy SOEs were exploring oil projects in Africa and Latin America as early as 1994, yet these were limited efforts. Given the priority of domestic energy sector development, overseas investments were not fully backed by the government at the time. In 1999, Chinese government launched the Going Global strategy and to actively push state firms to invest in overseas projects. To coordinate these efforts, Beijing established the State-owned Assets Supervision and Administration Commission (SASAC) under the State Council. Outward FDI flows climbed from less than \$1 billion in 2000 to \$12 billion in 2005 and \$69 billion in 2009. China became a net FDI exporter with $\$ 145$ billion in 2015. In 2016, FDI outflows reached a peak with $\$ 196$ billion while inflows remained at \$133 billion (UNCTAD 2019). By redirecting the trade surplus towards overseas infrastructure investments, the go out policy sought to relieve the pressure of overaccumulation by external expansion. In that sense, the go out strategy was a precursor to the BRI, which would take it to the next level.

A key objective of the go out policy was to reduce China's vulnerability stemming from dependence on global resource supply chains, particularly of vital resources. Instead of relying exclusively on market mechanisms for oil supply-the key manufacturing input for China's export processing industries- Beijing sought direct access to natural resources by acquiring equity shares and service contracts with oil producers. Virtually all energy-dependent countries are vulnerable to supply disruptions and market fluctuations, albeit in varying degrees. However, Chinese leadership's overwhelming concern with energy transit security, particularly the so-called Malacca Dilemma (Chaziza 2018; Len 2015) pushed Beijing to pursue mercantilist policies to control larger segments of the supply chain (Lind and Press 2018; F.-L. T. Yu 2017).

While mercantilist energy policies were deployed to alleviate the risks from reliance on global supply chains, dependence on global demand constituted a more complicated problem for Beijing. The 2008 global financial crisis and the collapse of global demand revealed the limits of China's export-oriented model. Already under pressure from overaccumulation and high labor costs, China's economy could potentially slide into recession due to external shock. Unemployment in export-oriented sectors would have posed a major threat to the political legitimacy of the regime. To cushion the impact of the crisis, Chinese leadership introduced in November 2008 a stimulus package of RMB 4 trillion (roughly $\$ 580$ billion at the time). The government relaxed credit by getting state-owned banks to lend, mostly to local governments, which then used the credit primarily for real estate development. 
In the short term, the stimulus package succeeded in saving Chinese economy from recession. By early 2010, however, the cash injection had been spent, and many local governments were in debt. (Jones and Zeng 2019,8). The long-term impact of the stimulus package was the aggravation of the crisis of capital overaccumulation. There already was a property bubble in many Chinese cities prior to 2009 (Davis 2011). The real estate development projects financed by local governments awash with stimulus cash led to a further saturation of the housing market. The "ghost town index" published by China Investment Network in 2014 noted around 50 virtually unoccupied new towns in China (Sum 2018, 4). The debt-financed construction boom exacerbated industrial overproduction. China's annual steel production increased from 512 million tons in 2008 to 803 million tons in 2015 (P. Cai 2017, 12). In 2015, steel consumption was 664 million tons, resulting in a surplus exceeding the total demand for steel in the US that year (about 100 million tons) (Statista 2019). Overcapacity approached 30 percent in iron, glass, cement, aluminum and power generation industries (Jones and Zeng 2019,8). As overproduction lowered prices, many SOEs faced negative returns on investment.

As excess capacity squeezed corporate profits and led to the rapid accumulation of debt, China's financial system became more vulnerable. To limit the adverse impact of the infrastructural bubble on the financial system, the central government intervened several times to tighten official credit. As credit became scarce, local governments and companies linked with them frequently turned to shadow banking for servicing debt (McMahon 2018). While policy interventions delayed the crisis, they failed to address the structural limitation of China's capital accumulation model: dependence on global value chains that China is unable to influence. Following decades of impressive export-driven economic growth, China faced progressively falling annual growth rates after 2010. The slowdown was partially the result of the 2008 crisis. Yet in the background of the falling growth rates were the structural issues accumulated throughout the last three decades of export-fueled growth. The availability of credit made the economy vulnerable to low-profit investments, which in turn opened the door to bad loans and debt. China's total external debt stocks have been climbing over the past two decades, at alarmingly higher rates since 2010. In 2017, China's external debt stocks were over $\$ 1.7$ trillion. Debt grew at a rate faster than GDP, which is the main cause of concern.

Economic pressures stemming from the dynamics of capital expansion were compounded by the dynamics of China's political regime. Competition among local governments in pursuit of financial subsidies fed back into excess capacity. To increase local growth figures and attract funds from the central government, local governments channeled investment into sectors that had already built up overcapacities. According to a 2018 S\&P report, "hidden" (off-balance-sheet) borrowings of local governments could be as high as 40 trillion yuan ( $\$ 5.78$ trillion), which has been labeled a "debt iceberg with titanic credit risks" (Reuters 2018a). The central government's concerns about performance legitimacy also disincentivized the policymakers from trimming industrial overcapacity, which would mean massive job losses without substitution and retraining mechanisms in place. It was in 2016 when Beijing finally announced a reduction of 1.8 million jobs in stateowned enterprises (1.3 million in coal and .5 million in steel industries). However, the central government's commitment to growth and employment "superseded the need to implement structural reforms"(Rolland 2017, 100).

Chinese leadership raised concerns about middle income trap (F. Cai 2012), the notion that countries that reach middle-income country status in a very short period of time may not be able to catch up with high-income economies (Glawe and Wagner 2019). In terms of global value chains, middle income trap indicates the precarious position of these economies which are competitive neither in labor intensive segments of production (due to high labor costs) nor in higher value-added activities (due to low labor productivity, technological limits). Transitioning from an economy dependent on cheap labor and abundant capital to one of high productivity requires structural reforms as well as new export markets for high value-added goods, particularly for countries like China with low domestic consumption rates. 
Next section discusses how the BRI seeks to overcome the structural limits of China's capital accumulation regime via externalization of development. The BRI not only pursues the exportation of surplus productive capacity but attempts to transform, connect and even create economic networks and regions in a way that would be conducive for further capital expansion. The goal is not just to diminish domestic liabilities but to transform them into external assets, which can be mobilized in pursuit of geopolitical as well as economic interests.

\section{From Domestic Liabilities to External Assets}

When Xi announced the "Silk Road Economic Belt" and 21 ${ }^{\text {st }}$ Century Maritime Silk Road" in 2013, he painted the initiative in broad strokes. At the time, the BRI was primarily perceived as an umbrella framework for various ongoing and planned regional infrastructure projects. Following Xi's announcement, officials from National Development and Reform Commission, Ministry of Foreign Affairs, and Ministry of Commerce worked on specifying the details of the initiative. Throughout 20132014, party leaders' statements suggested that the BRI would primarily target China's periphery, involving about 65 countries, mostly in Asia. During 2014 however, the BRI continued to expand to Eastern Africa and Europe. By 2015, the scope of the initiative became global, open to all countries (Jones and Zeng 2019, 10-11). In March 2015, National Development and Reform Commission and related agencies released "Vision and Actions on Jointly Building Silk Road Economic Belt and $21^{\text {st }}$ Century Maritime Silk Road" which remains the primary policy document outlining the guiding principles and areas of cooperation of the BRI (National Development and Research Commission 2015). Section III of "Vision and Actions" specifies not just one belt and one road but rather three land routes, two maritime routes and six corridors. ${ }^{1}$ Components contain multiple infrastructure projects, including railroads, ports, ports, pipelines as well as power production facilities, industrial parks, special economic zones and cities.

There is no official list of BRI projects. Given the increasingly ambiguous nature of the BRI as an umbrella term referring to virtually all investments abroad by China, it is problematic to identify which projects are part of the BRI at any given time. In a study of the six economic corridors, CSIS estimates that there are at least major 173 Chinese-funded and BRI-affiliated projects initiated between 2013 and 2017 in these corridors alone, including some colossal projects like the Gwadar Port in Pakistan. The majority of the BRI-related infrastructure activity so far seems to have focused on the China-Pakistan Economic Corridor, which is estimated to cost $\$ 68$ billion (Council on Foreign Relations 2019). China's overall expenses by 2027 is estimated at $\$ 1.3$ trillion (Morgan Stanley 2018).

How does the BRI help address China's problems of capital accumulation? As an infrastructure driven initiative, the BRI creates new external productive spaces that could absorb some of the excess capacity. In October 2013, trailing the initial announcement of the BRI by XI, State Council published a "guiding opinion" on "resolving the contradictions of overcapacity" where they suggested "actively expanding the external market" as a solution (State Council 2013). The construction of various roads, railroads, ports, new urban and industrial zones will create demand for China's steel, cement and other construction material. For instance, according to the Ministry of Industry and Informational Technology, $20000 \mathrm{~km}$ of new railways would absorb 85 million tons of steel (Holslag 2017, 49). While demand from the BRI countries may not be immediately sufficient to consume all excess production, taking the pressure off even partially can allow Beijing the much needed space for rebalancing the economy.

In addition to traditional industrial sectors weighed down by excess capacity, high tech industries like optical fiber and cable industries also accumulated a 50 percent overcapacity by the end of 2015 (H. Shen 2018, 2686). July 2015 State Council report identified the

\footnotetext{
${ }^{1}$ Land routes link China to Europe via Central Asia and Russia; to the Middle East via Central Asia and to India via Southeast Asia. Maritime routes reach to Europe via the Indian Ocean; and to the South Pacific via the South China Sea. The economic corridors are the New Eurasian Land Bridge, China-Mongolia-Russia, China-Indochina, ChinaCentral Asia-West Asia, Bangladesh-China-India-Myanmar and China-Pakistan corridors.
} 
telecommunications industry as one of the 13 sectors that needed to increase "international industrial cooperation" (State Council 2015). The so-called Digital Silk Road -the global network of fiber optic cables, international trunk passageways, mobile structures and standards like 5G networks - is partially driven by the need to find new outlets for the excess capacity in the Internet and communication sector. The Digital Silk Road also provides the infrastructure necessary for the internationalization of RMB (more on this below).

In addition to exporting construction material, China seeks to relocate entire domestic production facilities into the BRI countries. China currently has excess equipment for manufacturing steel, cement and other material. Beijing seeks to export its entire unwanted surplus industrial capacity to countries that are lower in the global value chains. This would not only allow production to take place closer to the markets but also facilitate China's industrial transition from labor intensive, mass manufacturing model (P. Cai 2017, 13) The process is well underway. Hebei, China's top steel making province, cut 98 million tons of steel making capacity and 86 million tons of iron making capacity between 2013 and 2018 (Reuters 2018b). The province seeks to relocate some of this capacity abroad by 2023.

The relocation of industrial capacity abroad is often framed as providing the developing world with "China development dividend" (Summers 2016, 1637). As Jin Qi, the Chairperson of the Silk Road Fund said, "China possesses high-quality industrial production capacity, equipment, and technology, ample supply of funds and 30 years of development experience" which can "help facilitate international production cooperation, and reorganize global production chain" (P. Cai 2017, 3). This rationale is partially informed by China's own industrialization experience in the 1980s and 1990s when Chinese manufacturers imported second-hand, surplus equipment and even complete lines from developed countries to jump start industrialization. By exporting its low-end manufacturing capacity, China perceives itself as replicating its experience with others. Beijing publicly denies that exportation of overcapacity has anything to do with the BRI and instead uses the term "international industrial cooperation." China's projects are portrayed as "magnanimous gifts to underdeveloped countries in desperate need of basic transportation networks or energy supplies to which China brings its experience in infrastructure construction" (Rolland 2017, 100). International industrial cooperation, it is argued, is "fundamentally different from the transfer of excess capacity practiced in the past by the developed countries" (Global Times 2016).

Critics however describe this process as a form of "spatial fix," (Sum 2018; Summers 2017; Zhang 2017), invoking Harvey's notion that inner crisis tendencies in capitalist societies generated a drive for geographical expansion and restructuring (Harvey 1982). The infrastructure projects implemented within the framework of the BRI are spatial fixes in and of themselves (Flint and Zhu $2018,4)$ as they facilitate the exportation of over accumulated capital. However, the distinctive feature of the BRI as a spatial fix, one that conceivably separates it from previous forms of capitalist expansion around the world is the BRI's emphasis on connectivity. The BRI seeks to reterritorialize economic activity by linking markets and producers, and by expanding, multiplying and inter-connecting trans-regional and global value chains. This reterritorialization via connectivity is fundamental to overcoming the structural problems of capital accumulation. Simply "dumping" the excess industrial capacity and capital on the underdeveloped and often politically unstable countries along the BRI will be likely insufficient. The geographic spaces that are targeted for investment must be connected so they can generate adequate economic returns to allow for capital expansion on a trans-regional scale.

The "Vision and Actions" defines five "connectivities" -policy coordination, facilities connectivity, unimpeded trade, financial integration, and people-to-people bonds - as the major goals of the BRI. In addition to hard infrastructure like roads and ports which facilitate the movement of goods and people, the BRI also aims at enhancing connectivity via soft infrastructure like Free Trade Agreements. Since the announcement of 2013, Beijing made a major effort to establish a global network of bilateral trade and investment ties. The majority of the BRI partners are in the process of negotiating with China. Many countries that already had agreements in place are renegotiating for revised and more comprehensive deals (Baltensperger and Dadush 2019). A 
key component of these new networks of capital is the creation of new urban centers, the nodes which are being interconnected via hard and soft infrastructure. According to China's Ministry of Commerce, at least 56 industrial parks are being built in 20 countries along the BRI (South China Morning Post 2017). The zones are conceived as industrial and commercial spaces, which would create employment and cultivate investment. Since 1980s, China put up dozens of similar zones in China, including Shenzhen, now a city of 12.5 million people. An example of special economic zones is the China-Belarus Industrial Park, established $25 \mathrm{~km}$ outside of Minsk in 2013. Funded primarily by the State Bank of China, the industrial park offers tax incentives to attract investment and create jobs. The expectation is that the park will become a "real city" by 2030 (China Daily 2017).

The analysis so far indicated that the problems of capital accumulation under China's exportoriented growth model indicates a particular form of spatial fix via the BRI, which goes beyond the exportation of excess industrial/financial capacity and seeks to transform external productive spaces by means of inter-regional connectivity via hard and soft infrastructure. The logic of connectivity structures the financing of the BRI as well. As massive as China's foreign exchange reserves are, given the scale of the BRI projects, Beijing will need to raise capital from other sources, if only to hedge against the considerable risks involved in financing long-term projects in highly volatile regions. According to Asian Development Bank, the "infrastructure gap" in Asia alone will be \$26 trillion by 2030. This is one reason why in October $2013 \mathrm{Xi}$ proposed a multilateral development bank dedicated to lending for infrastructure projects. The Asian Infrastructure and Investment Bank (AIIB) was established in October 2014 with an initial authorized capital of $\$ 100$ billion, about $\$ 30$ billion provided by China.

The BRI does not have a unified budget and draws funds from multiple sources. While AIIB is the most visible component of the financial structure of the BRI, in terms of the relative contributions to the BRI-related projects so far, AIIB resources are dwarfed by the commitments of Chinese national lending institutions. Lending institutions include the Silk Road Fund established in 2014 with a $\$ 40$ billion initial capital as well as China Investment Cooperation, China Development Bank (CDB), and the Export-Import Bank (EXIM). In June 2015, the CDB announced that it would invest a total of $\$ 890$ billion in 900 BRI projects (The Telegraph 2015). Indeed, even annual allocations of resources by CDB and EXIM far exceed that of the AIIB's total capital commitment (Jones and Zeng 2019, 14).

Despite its relatively limited resources, AIIB indicates a critical component in the establishment of new inter-regional and global financial networks, where China would be a central node. Throughout 2014 and 2015, Beijing conducted extensive economic diplomacy to establish a wide network of regional and non-regional (western) partners. Despite US efforts to dissuade allies from joining, UK became the first major western power to apply to be a founding member in March 2015. Germany, France, Italy, Australia, and South Korea followed suit. After lengthy negotiations among prospective founding members, the legal framework of AIIB was finalized in December 2015. AIIB is often conceived as part of China's efforts to offer an alternative to US-controlled financial institutions like the World Bank and IMF (K. G. Cai 2018). Beijing's discontent with the existing international economic governance is well-known (H. Yu 2017). Even after recent voting reforms, China's share in votes in IMF governance is about 6 percent, compared to US's 16 (IMF 2019). Thus, by spearheading the creation of new multilateral institutions, China seeks to close the gap between its economic power and its political clout in global governance. Within the governance structure of AIIB, China is the veto player with 26 percent voting power (AIIB 2019), enough to influence key decisions regarding membership and capital increases.

A key component of China's strategy of enhancing China's roles in financial networks is the internationalization of RMB. Even before the advent of the BRI, Beijing had been experimenting with financial mechanisms to enhance capital convertibility and the cross-border use of RMB (Huotari and Heep 2016). To facilitate trade settlements, China increased the number of RMB bilateral swap agreements with regional and non-regional actors, including Canada and Eurozone countries. Internationalization of Chinese currency is widely considered a critical aspect of China's 
geoeconomic strategy in an emergent multipolar order. While the objective is not to replace the US Dollar as the international reserve currency, the widespread use of RMB to settle international transactions would increase Beijing's economic and political influence. In addition to reputation gains, internationalization of its currency would allow greater flexibility with monetary policy. There are critical geopolitical benefits for other states, most notably the circumvention of US sanctions, which are increasingly based on the use of US Dollar. China's BRI lending through AIIB and policy banks spurs the internationalization of RMB as more countries accept the RMB to facilitate Chinese investment. While internationalization is a long and gradual process, data on trade settlements and foreign holdings in RMB since 2013 suggest an increased heft of the Chinese currency (Pugliese 2018). In 2016, RMB was included in the Special Drawing Rights of IMF, joining US Dollar, Euro, the Japanese Yen, and the British Pound.

China's infrastructure lending activities are criticized for being predatory. It is claimed that China offers funding to unsound projects to secure access to resources and local markets. As many of the countries that China invests in already have high debt/GDP ratios, the increased debt burden raises the probability of defaults. The fact that bilateral loan contracts China offers often lack transparency has led many to argue that Beijing lays out "debt traps" (Green 2019; The Economist 2018).The oft-cited example of the so-called debt diplomacy is the case of Sri Lanka. The government was about $\$ 8$ billion in debt to China in 2017, which included more than $\$ 300$ million for the Hambantota Port being constructed by China Merchant Port Holdings. Due to sluggish economic performance and low demand, Sri Lankan government could not repay concessional loans to China. China provided a four-year grace period but the interest rates for the port project were very high (at least twice as high as that of WB) (Graceffo 2017). Rather than rescheduling debt, Beijing offered to convert the debt into equity, acquiring 70 percent of the Hambantota port along with a 99-year lease for a surrounding industrial zone (Dutta 2017).

Beijing vehemently rejects the criticism of debt diplomacy, claiming that China has no intention of trapping other countries with debts. In line with the broader discourse of the BRI as an initiative of achieving shared growth through win-win collaboration, Beijing argues that the loans to Sri Lanka were simply a response to "Colombo's call for development" and "China cannot be blamed for Sri Lanka's debt quagmire" (S. Wang 2018). Others claim that funding for unsound project investments is driven by lobbying and politically minded credit allocation (Jones and Zeng $2019,14)$. Rather than elements of a dubious grand strategy of debt entrapment, investments like Hambantota are essentially products of poor economic design and decision-making.

In the absence of direct evidence that Chinese decision makers deliberately propose unsound projects as a pretext for procuring controlling stakes in the indebted countries, it is challenging to substantiate these claims. However, even if one does not presume that there is an explicitly manipulative, bait-and-switch rationale, China's loan-debt contractuality still serves a critical role in transforming internal economic liabilities into external economic and political assets. First, as discussed in the previous section, limits of internal capital accumulation necessitated productive channels for excess capacity, both as accumulated foreign exchange reserves and industrial production. Previous attempts to resolve this issue domestically, from the Great Western Development Program of 2000 to the 2008 stimulus package provided only limited relief in the short-term and aggravated the problem by lowering profitability and raising debt. BRI lending allows China to externalize its debt burden as loan-investment. A counter argument would be that by externalizing its debt, China is creating a vicious cycle of debt in the developing countries targeted by the BRI, which would eventually loop back into the Chinese economy. Given that most BRI investments are still in their infancy, it is difficult to estimate the level of systemic risk of debt sustainability. A report by the Center for Global Development indicates that of the 68 countries that were identified as potential BRI borrowers, eight were at particular debt distress based on lending associated by the BRI (Hurley, Morris, and Portelance 2018). Given the large and diversified investment portfolio, however, China can also hedge its bets and manage potential net gains/losses.

This takes us to the second and final point regarding the importance of loan-debt mechanisms as a strategic tool; the relative costs of exit from mutual dependence. While it is true that this is a 
relationship of interdependence based on mutual interest between the creditor and the debtor, the cost of severing the tie differs significantly for the two actors. Given the size of its economy and the total investment outflows of China, losses from sunk investments in any particular country will likely be less than the potential losses to the host country. Even when China does not purposefully set up and implement debt traps, the asymmetric distribution of exit costs provides Beijing with a certain degree of leverage. The net difference between the costs that China would incur from sunk investments (minus the value of any asset that may be acquired as a result) and the costs for the indebted country (increased debt/GDP ratio, loss of assets etc.) would indicate the size of the leverage China would have in any given relationship.

\section{Conclusion}

This article offered a political economy perspective which sought to bridge the analytical divide between the developmental and geopolitical perspectives. The primarily point of departure was that the BRI reflects Chinese state's effort to manage internal problems of capital accumulation by externalizing development on a trans-regional scale. China's problems of capital accumulation, it has been argued, primarily stem from dependence on global value chains over which the Chinese state and capital have limited control over. By expanding capital outward, China seeks to reduce its vulnerability stemming from its own dependence on global value chains.

The article has also argued that what separates the BRI from historical instances of capitalist expansion is the emphasis on connectivity. Rather than simply exporting export capacity onto developing countries, the BRI seeks to reorganize the external economic space, aiming to render it more suitable for capital expansion. In the process of creating new nodes and networks of trade, investment and production, China also creates new asymmetric interdependencies. The article briefly discussed two instances of such new asymmetries favoring China: internationalization of RMB and loan-debt relations. To the extent that such asymmetric dependencies can be leveraged for strategic purposes, the BRI can be construed as a geopolitical as well as developmental initiative.

\section{References}

AIIB. 2019. "Members of the Bank." https://www.aiib.org/en/about-aiib/governance/members-of-bank/index.html (May 17, 2019).

Allison, Graham. 2017. Destined for War: Can America and China Escape Thucydides's Trap? Houghton Mifflin Harcourt.

Amighini, Alessia. 2015. "Growth. Heading to a 'New Normal."” In Xi's Policy Gambles: The Bumpy Road Ahead, eds. Alessia Amighini and Axel Berkofsky. ISPI.

Asian Development Bank. 2017. "Asia Infrastructure Needs Exceed \$1.7 Trillion Per Year, Double Previous Estimates." Asian Development Bank. Accessed May 17, 2019. https://www.adb.org/news/asia-infrastructureneeds-exceed-17-trillion-year-double-previous-estimates.

Baldwin, Richard. 2006. "Globalisation: The Great Unbundling(s).” Economic Council of Finland 20(3).

Baltensperger, Michael, and Uri Dadush. 2019. The Belt and Road Turns Five. Bruegel.

Beckley, Michael. 2018. Unrivaled: Why America Will Remain the World's Sole Superpower. Cornell: Cornell University Press.

Bijian, Zheng. 2017. “China's 'One Belt, One Road' Plan Marks The Next Phase Of Globalization.” New Perspectives Quarterly 34(3): 27-30.

Blackwill, Robert D., and Jennifer M. Harris. 2016. War by Other Means: Geoeconomics and Statecraft. Harvard University Press.

Blanchard, Jean-Marc F. 2017. "Probing China's Twenty-First-Century Maritime Silk Road Initiative (MSRI): An Examination of MSRI Narratives." Geopolitics 22(2): 246-68.

Cabestan, Jean-Pierre. 2018. "Beijing's 'Going Out' Strategy and Belt and Road Initiative in the Sahel: The Case of China's Growing Presence in Niger.” Journal of Contemporary China: 1-22.

Cai, Fang. 2012. "Is There a 'Middle-Income Trap'? Theories, Experiences and Relevance to China." China \& World Economy 20(1): 49-61.

Cai, Kevin G. 2018. "The One Belt One Road and the Asian Infrastructure Investment Bank: Beijing's New Strategy of Geoeconomics and Geopolitics.” Journal of Contemporary China 0(0): 1-17.

Cai, Peter. 2017. Understanding China's Belt and Road Initiative. Lowy Institute for International Policy. 
Callahan, William A. 2016. "China's 'Asia Dream': The Belt Road Initiative and the New Regional Order.” Asian Journal of Comparative Politics 1(3): 226-43.

CGTN. 2017. "Full Text of Xi Jinping Keynote at the World Economic Forum." CGTN America. Accessed May 17, 2019. https://america.cgtn.com/2017/01/17/full-text-of-xi-jinping-keynote-at-the-world-economic-forum.

Chang-Liao, Nien-chung. 2016. “China's New Foreign Policy under Xi Jinping.” Asian Security 12(2): 82-91.

Chaziza, Mordechai. 2018. "The Chinese Maritime Silk Road Initiative.” Mediterranean Quarterly 29(2): 54-69.

Chin, Gregory T. 2015. "China’s Bold Economic Statecraft.” Current History; Philadelphia 114(773): $217-23$.

China Daily. 2017. “China-Belarus Industrial Park Makes Breakthrough in Attracting Investors.” Accessed May 17, 2019. http://www.chinadaily.com.cn/business/2017-10/12/content_33154129.htm.

Clarke, Michael. 2018. “The Belt and Road Initiative: Exploring Beijing’s Motivations and Challenges for Its New Silk Road." Strategic Analysis 42(2): 84-102.

Council on Foreign Relations. 2019. "China's Massive Belt and Road Initiative." Accessed May 17, 2019. https://www.cfr.org/backgrounder/chinas-massive-belt-and-road-initiative.

Davis, Bob. 2011. "The Great Property Bubble of China May Be Popping." Wall Street Journal. https://www.wsj.com/articles/SB10001424052702304906004576367121835831168 (April 26, 2019).

Defense Intelligence $\quad 2019 . \quad$ China Military http://www.dia.mil/Portals/27/Documents/News/Military\%20Power\%20Publications/China_Military_Power_FI NAL_5MB_20190103.pdf(January 16, 2019).

Diplomat, Shannon Tiezzi, The. 2014. "The New Silk Road: China's Marshall Plan?" The Diplomat. https://thediplomat.com/2014/11/the-new-silk-road-chinas-marshall-plan/ (March 15, 2019).

Dutta, Prabhash K. 2017. "Sri Lanka Leases Hambantota Port to China for Non-Military Use. Should India Worry?" India Today. Accessed May 17, 2019. https:/www.indiatoday.in/india/story/sri-lanka-leases-hambantota-portchina-non-military-use-india-worry-1027012-2017-07-29.

EPS China Data. 2019. “EPS China Data.” Accessed May 17, 2019. http://www.epschinadata.com/.

Ferdinand, Peter. 2016. "Westward Ho - the China Dream and 'One Belt, One Road': Chinese Foreign Policy under Xi Jinping." International Affairs 92(4): 941-57.

Flint, Colin, and Cuiping Zhu. 2018. "The Geopolitics of Connectivity, Cooperation, and Hegemonic Competition: The Belt and Road Initiative." Geoforum. http://www.sciencedirect.com/science/article/pii/S0016718518303634 (January 23, 2019).

Glawe, Linda, and Helmut Wagner. 2019. "China in the Middle-Income Trap?" China Economic Review. http://www.sciencedirect.com/science/article/pii/S1043951X19300033 (April 15, 2019).

Global Times. 2016. "China Exporting Industrial Benefits, Not Overcapacity." http://www.globaltimes.cn/content/974284.shtml (May 17, 2019).

Graceffo, Antonio. 2017. "China's Push for the One Belt One Road (OBOR) Initiative." Foreign Policy Journal. Accessed May 17, 2019. https://www.foreignpolicyjournal.com/2017/05/15/chinas-push-for-the-one-belt-oneroad-obor-initiative/.

Green, Mark. 2019. "China's Debt Diplomacy.” Foreign Policy. https://foreignpolicy.com/2019/04/25/chinas-debtdiplomacy/ (April 27, 2019).

Harrell, Peter, Elizabeth Rosenberg, and Edoardo Saravalle. 2018. China's Use of Coercive Economic Measures. Center for New American Security.

Harvey, David. 1982. The Limits to Capital. Oxford: B. Blackwell.

Holslag, Jonathan. 2017. "How China’s New Silk Road Threatens European Trade." The International Spectator 52(1): 46-60.

Huotari, Mikko, and Sandra Heep. 2016. "Learning Geoeconomics: China's Experimental Financial and Monetary Initiatives.” Asia Europe Journal 14(2): 153-71.

Hurley, John, Scott Morris, and Gailyn Portelance. 2018. Examining the Debt Implications of the Belt and Road Initiative from a Policy Perspective. Center for Global Development.

IMF. 2019. "IMF Members' Quotas and Voting Power, and IMF Board of Governors.” Accessed May $17,2019$. https://www.imf.org/external/np/sec/memdir/members.aspx.

Jones, Lee, and Jinghan Zeng. 2019. 'Understanding China's 'Belt and Road Initiative': Beyond 'Grand Strategy' to a State Transformation Analysis." Third World Quarterly: 1-28.

Lee, Yaechan. 2018. "Economic Interdependence and Peace: A Case Comparison Between the US-China and US-Japan Trade Disputes." East Asia 35(3): 215-32.

Len, Christopher. 2015. "China's 21st Century Maritime Silk Road Initiative, Energy Security and SLOC Access." Maritime Affairs: Journal of the National Maritime Foundation of India 11(1): 1-18.

Li, Yuan, and Markus Taube. 2018. "The Implications of the 'Belt and Road Initiative' on Globalization and Inclusive Growth for the Eurasian Continent.” Journal of Chinese Economic and Business Studies 16(3): 233-40.

Lind, Jennifer, and Daryl G. Press. 2018. "Markets or Mercantilism? How China Secures Its Energy Supplies." International Security 42(04): 170-204.

Macaes, Bruno. 2019. Belt and Road: A Chinese World Order. Oxford, New York: Oxford University Press.

Mayer, Maximilian. 2018. "China's Rise as Eurasian Power: The Revival of the Silk Road and Its Consequences.” In Rethinking the Silk Road, ed. Maximilian Mayer. Singapore: Springer Singapore, 1-42. http://link.springer.com/10.1007/978-981-10-5915-5_1 (October 30, 2018). 
McMahon, Dinny. 2018. China's Great Wall of Debt: Shadow Banks, Ghost Cities, Massive Loans, and the End of the Chinese Miracle. Boston: Houghton Mifflin Harcourt. Accessed May 17, 2019. https://www.amazon.com/Chinas-Great-Wall-Debt-Massive/dp/1328846016/ref=sr_1_1?keywords=china+wall+ debt\&qid=1558241774\&s=gateway\&sr=8-1.

Mearsheimer, John J. 2014. "Can China Rise Peacefully?" The National Interest. https://nationalinterest.org/commentary/can-china-rise-peacefully-10204 (May 17, 2019).

Ministry of Foreign Affairs of the People's Republic of China. 2015. "Foreign Minister Wang Yi Meets the Press." Accessed May 17, 2019. https://www.fmprc.gov.cn/mfa_eng/zxxx_662805/t1243662.shtml.

Ministry of Foreign Affairs of the People's Republic of China. 2018. "Wang Yi: The Belt and Road Initiative Is Not a 'Marshall Plan' but a Vivid Practice of Jointly Building a Community with a Shared Future for Mankind." Accessed May 17, 2019. https://www.fmprc.gov.cn/mfa_eng/zxxx_662805/t1588358.shtml.

Morgan Stanley. 2018. “Inside China's Plan to Create a Modern Silk Road.” Morgan Stanley. Accessed May 17, 2019. https://www.morganstanley.com/ideas/china-belt-and-road.

National Development and Research Commission. 2015. "Vision and Actions on Jointly Building Silk Road Economic Belt and 21st-Century Maritime Silk Road.” http://en.ndrc.gov.cn/newsrelease/201503/t20150330_669367.html (January 14, 2019).

Norris, William J. 2016. Chinese Economic Statecraft: Commercial Actors, Grand Strategy, and State Control. Ithaca ; London: Cornell University Press.

Pugliese, Michael D. 2018. "Internationalization of the RMB: A Progress Report."

Reilly, James. 2013. China's Economic Statecraft: Turning Wealth into Power. Lowy Institute for International Policy.

Reuters. 2018a. “China Local Governments' Hidden Debt Could Total \$5.8 Trillion: S\&P.” Accessed May 17, 2019. https://www.reuters.com/article/us-china-economy-debt/china-local-governments-hidden-debt-could-total-5-8trillion-sp-idUSKCN1MQ0JH.

Reuters. 2018b. "China's Hebei Aims to Cut Iron, Steel Making Capacity by 20 Million T in 2018." Accessed May 17, 2019. https://www.reuters.com/article/us-china-steel-hebei/chinas-hebei-aims-to-cut-iron-steel-making-capacityby-20-million-t-in-2018-idUSKCN1GK0KV.

Rolland, Nadage. 2017. China's Eurasian Century? Political and Strategic Implications of the Belt and Road Initiative. The National Bureau of Asian Research.

Shen, Hong. 2018. "Building a Digital Silk Road? Situating the Internet in China's Belt and Road Initiative." International Journal of Communication 12: 2683-2701.

Shen, Simon, and Wilson Chan. 2018. "A Comparative Study of the Belt and Road Initiative and the Marshall Plan." Palgrave Communications 4(1). http://www.nature.com/articles/s41599-018-0077-9 (January 14, 2019).

Sidaway, James D., and Chih Yuan Woon. 2017. “Chinese Narratives on 'One Belt, One Road' (一带一路) in Geopolitical and Imperial Contexts.” The Professional Geographer 69(4): 591-603.

South China Morning Post. 2017. "Belt and Road Corridors See More Technology and Industrial Parks as China's Influence Spreads.” https://www.scmp.com/special-reports/business/topics/special-report-belt-and$\mathrm{road} /$ article/2099303/belt-and-road-corridors (May 17, 2019).

State Council. 1997. “1997 State Council Work Report.” http://www.gov.cn/test/2006-02/16/content_201124.htm (May 17, 2019).

State Council. 2013. "Guiding Opinions of the State Council on Resolving the Contradictions of Serious Overcapacity." Accessed May 17, 2019. http://www.gov.cn/zwgk/2013-10/15/content_2507143.htm.

State Council. 2015. "State Council's Guiding Opinions on Promoting International Capacity and Equipment Manufacturing Cooperation (Guo Fa [2015] No. 30)_Government Information Disclosure Column.” Accessed May 17, 2019. http://www.gov.cn/zhengce/content/2015-05/16/content_9771.htm.

Statista. 2019. "U.S. Steel Demand - Apparent Consumption 2013-2018." Accessed May $17,2019$. https://www.statista.com/statistics/268683/us-steel-demand-since-2008/.

Sum, Ngai-Ling. 2018. “The Intertwined Geopolitics and Geoeconomics of Hopes/Fears: China's Triple Economic Bubbles and the 'One Belt One Road' Imaginary." Territory, Politics, Governance: 1-25.

Summers, Tim. 2016. "China's 'New Silk Roads': Sub-National Regions and Networks of Global Political Economy." Third World Quarterly 37(9): 1628-43.

Summers, Tim. 2017. "Rocking the Boat." In China's Presence in the Middle East: The Implications of the One Belt, One Road Initiative, Routledge, 24-37.

The Economist. 2018. "The Perils of China's 'Debt-Trap Diplomacy." The Economist. https://www.economist.com/asia/2018/09/06/the-perils-of-chinas-debt-trap-diplomacy (April 27, 2019).

The Telegraph. 2015. "China to Invest $\$ 900$ Billion in Belt and Road Initiative." The Telegraph. https://www.telegraph.co.uk/china-watch/business/china-billion-dollar-belt-road-initiative/ (May 17, 2019).

UNCTAD. $2019 . \quad$ "UNCTADstat." https://unctadstat.unctad.org/EN/?fbclid=IwAR1NSez0ri9bqXDrDJ5Z0lcaVnb6nx9DDIWgkflDLLgQE8gqu15Ekv0mYk (May 17, 2019).

Wang, Se. 2018. "Western Media Misread Sri Lanka’s Debt Issue - Global Times.” Global Times. Accessed May 17, 2019. http://www.globaltimes.cn/content/1110850.shtml.

Wang, Yong. 2016. "Offensive for Defensive: The Belt and Road Initiative and China's New Grand Strategy." The Pacific Review 29(3): 455-63. 
World Bank. 2018. "Belt and Road Initiative.” Accessed May 17, 2019. http://www.worldbank.org/en/topic/regionalintegration/brief/belt-and-road-initiative.

World Bank.. 2019. "World Bank Open Data.” https://data.worldbank.org/ (May 17, 2019).

Wright, Thomas. 2013. "Sifting through Interdependence.” The Washington Quarterly 36(4): 7-23.

Xiaotong, Zhang, and James Keith. 2017. "From Wealth to Power: China's New Economic Statecraft." The Washington Quarterly 40(1): 185-203.

Xinhua. 2017. "Full Text of President Xi's Speech at Opening of Belt and Road Forum." http://www.xinhuanet.com/english/2017-05/14/c_136282982.htm (May 17, 2019).

Yu, Fu-Lai Tony. 2017. "Neo-Mercantilist Policy and China's Rise as a Global Power." Contemporary Chinese Political Economy and Strategic Relations; Kaohsiung 3(3): 1043-1073,XV.

Yu, Hong. 2017. "Motivation behind China's 'One Belt, One Road' Initiatives and Establishment of the Asian Infrastructure Investment Bank.” Journal of Contemporary China 26(105): 353-68.

Zhang, Xin. 2017. "Chinese Capitalism and the Maritime Silk Road: A World-Systems Perspective." Geopolitics 22(2): 310-31. 